\title{
Pengaturan Kewenangan Notaris Melakukan Pengesahan Fotokopi Surat dengan Aslinya
}

\author{
I Dewa Gede Ngurah Anandika Atmaja ${ }^{1}$
}

1Program Studi Magister (S2) Kenotariatan Fakultas Hukum Universitas Udayana, BaliIndonesia, E-mail : E-mail: ngurahanandika@yahoo.co.id

\section{Info Artikel \\ Keywords : \\ Notary, Endorsement, \\ Photocopy and Original Letter \\ Notary, Endorsement, \\ Photocopy and Original Letter}

Kata kunci:

Notaris, Pengesahan, Fotokopi

Dan Surat Aslinya.

Corresponding Author:

I Dewa Gede Ngurah Anandika Atmaja, E-mail: ngurahanandika@yahoo.co.id

\begin{abstract}
Article 15 paragraph (2) letter d UUJN-P concerning the authority of Notaries to approve the suitability of a photocopy with the original letter there is an obscurity of legal norms which gives rise to multiple interpretations in terms of validating the suitability of photocopies made by a Notary in accordance with the original letter which does not provide clarity of understanding of how the Notary to do matching and any letter that can be validated by a Notary. The writing of this journal aims to develop Notary Legal Science that examines the authority of the Notary to validate the suitability of the photocopy with the original letter. The study of scientific journal writing uses a type of normative research that departs from the obscurity of legal norms Article 15 paragraph (2) letter d UUNJ$P$ regarding the authority of a Notary to authorize the compatibility of a photocopy with the original letter. The results of this journal research is legal certainty Article 15 paragraph (2) letter $d$ UUJN-P related to the authority of the Notary in validating the suitability of the photocopy with the original letter there is still a vague legal norm that does not provide clarity of understanding of how the Notary does the matching and what letter matching validation can be done. The authority of the Notary in ensuring the correctness of the suitability of the photocopy with the original letter whether or not having the authority in the study of the author is a Notary having the authority stipulated in the provisions of Article 15 paragraph (2) letter d UUJN-P but in this case it needs to be corrected in the future considering UUJN-P is not provide legal certainty to the extent of the authority of the Notary in validating the suitability of the photocopy with the original letter.
\end{abstract}

\section{Abstrak}

Berdasarkan Pasal 15 ayat (2) huruf d Undang-Undang Nomor 2 Tahun 2014 tentang Perubahan Atas Undang Undang Nomor 30 Tahun 2004 tentang Jabatan Notaris mengenai kewenangan Notaris melakukan pengesahan kesesuaian fotokopi dengan surat aslinya terdapat kekaburan norma hukum yang menimbulkan multitafsir dalam hal pengesahan kecocokan fotokopi yang dilakukan oleh Notaris sesuai dengan surat aslinya yang tidak memberikan kejelasan pemahaman tentang bagaimana 
DOI :

10.24843/AC.2018.v03.i03.p1

2

\section{Pendahuluan}

Notaris kelembagaannya masuk ke Negara Indonesia awal abad XVII hal ini berbarengan dengan Vereenigde Oost Ind. Compagnie (VOC). ${ }^{1}$ Fungsi Notaris pada saat itu memberikan suatu pelayanan terhadap warga penduduk serta para pedagang. Pelayanan yang diberikan diantarnya memberikan semua pelayanan yang berkaitan dengan surat seperti surat dibawah tangan (codicil), akta perjanjian perdagangan, perjanjian kawin, surat wasiat (testament), serta hal-hal yang dianggap perlu. ${ }^{2}$ Pada saat itu Notaris pertama di Indonesia, yaitu Melchione Kerchem yang berkedudukan di Jakarta diangkat pada tanggal 27 Agustus 1620.3

Pada umumnya Notaris merupakan pejabat umum yang dapat melaksanakan tugasnya untuk memberikan suatu pelayanan kepada masyarakat umum di bidang Hukum Perdata dalam pembuatan akta otentik. Fungsi utama dari Notaris membuat

${ }^{1}$ Diatmika, I. G. A. O., Atmadja, I. D. G., \& Utari, N. K. S. (2014). Perlindungan Hukum Terhadap Jabatan Notaris Berkaitan Dengan Adanya Dugaan Malpraktek Dalam Proses Pembuatan Akta Otentik. Acta Comitas, 150-160. hal. 154.

2 Adjie, H. (2008). Hukum Notaris Indonesia (Tafsir Tematik Terhadap UU No.30 tahun 2004 Tentang Jabatan Notaris). Bandung: Refika Aditama. hal. 3

${ }^{3}$ Hendra, R. (2011). Tanggungjawab Notaris Terhadap Akta Otentik Yang Penghadapnya Mempergunakan Identitas Palsu di Kota Pekanbaru. Jurnal Ilmu Hukum Riau, 3(01). hal.5. 
akta otentik dan hal ini diatur dalam ketentuan Pasal 1870 Kitab Undang-undang Hukum Perdata. Substansi dalam akta otentik pada intinya dianggap sebagai alat bukti tertulis yang tidak perlu dibuktikan dengan alat bukti lainya maka dari itu akta autentik merupakan alat pembuktian yang sempurna. Untuk itu Notaris dalam melaksaknakan tugasnya membuat akta otentik guna memberikan kepastian hukum kepada masyarakat mengacu pada ketentuan Undang-Undang Jabatan Notaris (selanjutnya disebut UUJN-P) agar terwujudnya jaminan kepastian hukum dan perlindungan hukum yang benar dan adil.

Berdasarkan Pasal 1 UUN-P menentukan Notaris adalah pejabat umum yang berwenang untuk membuat akta autentik dan memiliki kewenangan lainnya sebagaimana dimaksud dalam undang-undang ini atau berdasarkan undang-undang lainnya. Adapun kewenangan dalam menjalankan jabatannya sesuai dengan Pasal 15 ayat (1), (2) dan (3) UUJN-P.

Dari ketentuan pasal 15 UUJN-P tersebut menetukan adanya kepastian apasaja kewenangan Notaris dalam melaksanakan tugasnya sebagai Pejabat Umum. Pada dasarnya kewenangan Notaris dalam ketentuan UUJN-P tersebut dapat diartikan bahwa kewewenang Notaris sebagai pejabat umum meliputi:

1. Notaris memiliki dasar kewenangan dengan akta yang dibuatnya;

2. Notaris memiliki dasar kewenangan mengenai kepentingan siapa akta tersebut dibuat;

3. Notaris memiliki dasar kewenangan mengenai dimana akta tersebut dibuat berdasarkan waktu dan tempat akta tersebut diterbitkan.

Seperti halnya kewenangan Notaris dalam melaksanakan jabatanya sebagai pejabat umum. Kewenangan berdasarkan ketentuan pasal 15 UUNJ-P telah mengatur mengenai kewenangan apasaja yang dapat dilaksanakan sebagai Notaris. Dalam ketentuan Pasal 15 UUJN-P tersebut terdapat kewenangan yakni kewenangan Notaris melakukan pengesahan kecocokan fotokopi dengan surat aslinya (legalisir). ${ }^{4}$

Dengan kewenangan Notaris melaksanakan pengesahan kecocokan fotokopi dengan surat aslinya, penulis berpendapat adanya kekaburan norma hukum dalam penerapan pasal tersebut. Artinya dalam ketentuan kewenangan yang terdapat didalam ketentuan Pasal 15 ayat (2) huruf d UUJN-P mengenai kewenangan Notaris untuk dapat melakukan pengesahan persesuaian fotokopi dengan surat aslinya. Kekaburan norma yang penulis maksud dalam kajian penulisan ini adalah adanya suatu aturan kewenagan yang dicantumkan dalam ketentuan UUJN-P menimbulkan ketidak pahaman dalam melaksanakannya. Maksud dari ketidak pahaman dalam Pasal 15 ayat (2) huruf d UUJN-P, bagaimana cara Notaris dapat melakukan pengesahan fotokopi surat sesuai dengan aslinya tidak dapat. Apabila dilihat dari kondisi perkembangan teknologi dan informasi semakin cepat dan semakin canggih pada saat ini kewenangan Notaris untuk bagaimana cara Notaris untuk dapat mengetahui keaslian terhadap mengesahkan fotokopi surat sesuai dengan aslinya. Padahal dalam ketentuan pasal tersebut Notaris diwajibkan mengetahui keaslian surat atau dokumen yang diberikan oleh para pihak penghadap untuk dapat melakukan pengesahan sesaui dengan yang asli. Kembali lagi seperti halnya teknologi seperti sekarang ini sesuatu yang asli tidak

${ }^{4}$ Ghofur, A. (2009). Lembaga Kenotariatan Indonesia. Yogyakarta: UUI Press. hal.13. 
dapat dilhat dan dicocokan begitu saja.

Pengesahan kecocokan fotokopi yang dilakukan oleh Notaris sesuai dengan surat aslinya seharusnya dapat memberikan kejelasan pemahaman tentang bagaimana cara Notaris untuk mengetahui keaslian surat atau dokumen bahwa yang diberikan oleh para pihak adalah asli. Sehingga Notaris dapat melakukan pencocokan dan surat apa saja yang bisa dilakukan pengesahan copi dengan yang asli yang dilakukan pencocokan oleh Notaris.

Berdasarkan uraian latar belakang diatas terdapat adanya kekaburan norma hukum terkait dengan penafsiran kewenangan Notaris untuk melakukan pengesahan kecocokan fotokopi dengan surat aslinya. Dengan adanya permasalahan hukum tersebut, penulis tertarik untuk membuat suatu jurnal penelitian ilimiah yang berjudul "Pengaturan Kewenangan Notaris Melakukan Pengesahan Fotokopi Surat Dengan Aslinya".

Mengenai uraian dari latar belakang tersebut diatas terdapat 2 (dua) rumusan masalah dalam penulisan jurnal ini diantaranya: Bagaimanakah kepastian hukum Pasal 15 ayat 2 huruf d UUJN-P terkait kewenangan Notaris dalam melakukan pengesahan kecocokan fotokopi dengan surat aslinya? dan Apakah Notaris dapat memastikan kebenaran dalam kesesuaian fotokopi dengan surat aslinya?

Tujuan dalam penulisan ini, secara umum penulisan ini bertujuan untuk dapat mengembangkan Ilmu Hukum dibidang Hukum Kenotariatan. Penulisan dalam jurnal ini menganalisa mengenai kewenangan Notaris dalam melaksanakan kewenagannya untuk melakukan pengesahan kecocokan fotokopi dengan surat aslinya. Sedangkan tujuan khusus dalam penulisan jurnal ini adalah untuk dapat menganalisis dan mengevaluasi Notaris dalam melaksanakan kewenanganya untuk membuat akta autentik serta mengevaluasi bagaimana sebaiknya pengaturan Notaris dalam melaksanakan kewengannya untuk melakukan pengesahan kecocokan fotokopi dengan surat aslinya.

Manfaat teoritis dari hasil penelitian dapat digunakan sebagai kontribusi dalam mengembangkan ilmu hukum, khususnya pada bidang hukum kenotariatan. Hasil dari penelitian ini diharapkan dapat memberikan suatu manfaat bagi perkembangan pengetahuan mengenai kepastian hukum yang terdapat dalam Pasal 15 ayat (2) huruf d UUJN-P. Sehingga peraturan Notaris dalam melaksanakan kewenangannya untuk dapat melakukan pengesahan kecocokan fotokopi dengan surat aslinya dapat dilaksanakan tanpa harus menafasirkan terlebih dahulu. Sedangkan menganai manfaat praktis dalam penelitian diharpkan dapat memberikan kontribusi kepada Notaris, akademisi, peneliti serta masyarakat. Manfaat bagi Notaris dari hasil penelitian ini, dapat memberikan suatu pemahaman mengenai standar atau syarat bagi seorang Notaris dalam melaksanakan jabatannya dalam pembuatan akta autentik. Bagi kalangan akademisi dalam penelitian ini dapat memberikan suatu ide baru dan dapat menghasilkan suatu konsep dari sudut pandangan lain yang terkait dengan peraturan kewenangan Notaris dalam melaksanakan kewenangannya melakukan pengesahan kecocokan fotokopi dengan surat aslinya. Manfaat penelitian bagi peneliti dan masyarakat diharapkan kedepannya dapat memberikan manfaat serta memberikan sumbangan pemikiran bagi penelita dan masyarakat khususnya dalam hal 
perlindungan hukum apabila dalam pembuatan akta terdapat suatu kecacatan hukum sehingga lebih mematangkan diri bagi peneliti dan masyarakat mengenai peraturan Notaris dalam melaksanakan kewenangannya melakukan pengesahan kecocokan fotokopi dengan surat aslinya.

\section{Metode Penelitian}

Menurut Soerjono Soekanto yang dikutip dari buku Zainuddin Ali yang berjudul Metode Penelitian Hukum bahwa suatu penelitian hukum merupakan suatu kegiatan ilmiah yang didasari oleh metode, sistematika dan pemikiran tertentu, bertujuan untuk mempelajari sesuatu gejala hukum dengan cara menganalisanya. ${ }^{5}$ Dalam penulisan jurnal ini meggunakan penulis menggunakan jenis penelitian normatif. Penulisan jurnal ini beranjak dari adanya kekaburan norma hukum yang terdapat dalam ketentuan Pasal 15 ayat (2) huruf d UUNJ-P.

\section{Hasil Dan Pembahasan}

\subsection{Kewenangan Notaris Indonesia.}

Secara administratif Notaris mempunyai keterkaitan yang tidak dapat dipisahkan dengan Negara. Hal tersebut dikarenakan, pemerintahan dengan Notaris sangat berkaitan dengan pengangkatan dan pemberhentian Notaris. Menurut pendapat Komar Andasasmita menyatakan adanya karakteristik Notaris yang didapat serta dilihat dari 2 (dua) kelompok utama diantaranya Notariat functional dan Notariat profesional. 6

Apabila dilihat dalam pengertiannya Notariat functional merupakan pendelegasian wewenang pemerintah (gedelegeerd), wewenang pemerintah ini delegasi yang dinilai berdasarkan nilai kebenaran, memiliki kekuatan bukti formal serta mempunyai kekuatan eksekusi. Negara yang menerapkan sistem ini, terdapat pemisahan yang keras antara pekerjaan-pekerjaan yang didasarkan berdasarkan ketentuan undangundang, dimana dalam pemahaman tersebut Notariat. Indonesia menganut sistem ini.

Pemahaman Notariat profesional merupakan kelompok yang karakteristiknya adalah aturan yang dikeluarkan oleh pemerintah bukan untuk kepentingan diri Notaris sendiri namun untuk kepentingan masyarakat yang membutuhkan jasanya. Notaris yang menganut paham profesionalisme dalam produk hukumnya seperti akta, tidak mempunyai akibat khusus tentang kebenarannya, kekuatan bukti demikian kekuatan eksekutorialnya.

Dalam melaksanakan suatu perbuatan pemerintah harus memiliki dasar peraturan yang sah mengenai kewenangan dalam menjalankan jabatanya. Tanpa adanya suatu peraturan kewenangan yang sah maka pejabat atau badan usaha negara tidak dapat melaksanakan suatu perbuatan pemerintah. Setiap kewenangan pada dasarnya harus dilandasi dengan aturan hukum sebagai ketentuan dan/atau batasan agar dapat dijalankan dengan baik bahkan tidak bertentangan dengan kewenangan lainnya. Demikian juga mengenai kewenangan Notaris Indoneisa yang pada umumnya

\footnotetext{
${ }^{5}$ Ali, Z. (2009). Metode Penelitian Hukum. Jakarta: Sinar Grafika. hal.18.

${ }^{6}$ Haris, M. (2018). Kewenangan Notaris sebagai Pejabat Lelang Kelas II dalam Memberikan Penyuluhan Hukum atas Akta Risalah Lelang yang Dibuatnya. Syariah: Jurnal Hukum dan Pemikiran, 17(1). hal.54
} 
ketentuan tersebut diatur dalam ketentuan UUJN-P yang menyatakan Notaris adalah pejabat umum maka dalam melakukan suatu tindakan kewenangan harus berdasarkan ketentuan undang-undang atau peraturan yang ditentukan mengenai kewenangan Notaris. Dengan demikian Notaris yang melakukan tugasnya diluar dari kewenangan yang telah ditentukan dapat diklasifikasikan sebagai melanggar kewenangan. Notaris yang menjalankan profesinya sangat diharuskan memberikan jaminan kepastian hukum dan menjaga profesionalitas dalam pelayanannya.$^{7}$

Jabatan Notaris adalah perpanjangan tangan pemerintah dibidang jasa yang dibentuk untuk memberikan pelayanan kepada masyarakat dibidang hukum perdata. ${ }^{8}$ Inti dari tugas Notaris adalah mengkonstatir atau mencatat peristiwa atau bantuan jasa Notaris terhadap hubungan hukum antara para pihak yang menghadap Notaris. Sebagai pejabat umum peraturan kewenangan Notaris, merupakan kewenangan yang tidak pernah diberikan kepada pejabat-pejabat lainya. Kewenangan dapat dibagi menjadi 3 (tiga) bagian diantaranya kewenangan secara atribusi, delegasi dan mandat. ${ }^{9}$ Mengenai kewenangan sebagai Notaris didapat secara atribusi. Kewenangan yang didapat secara atribusi merupakan kewenangan yang melekat pada jabatan yang diemban oleh seseorang. Apabila kewenangan itu kurang sempurna, berarti keputusan yang berdasarkan kewenangan itu tidak sah menurut hukum atau ketentuan undangundang". ${ }^{10}$

Peraturan kewenangan Notaris yang dibentuk secara atribusi merupakan suatu jaminan secara legalitas dari pelaksanaan kewenangan tersebut. Oleh karena itu kewenangan Notaris dalam melaksanakan tuganya ditentukan dalam ketentuan Pasal 15 UUJN-P. Dalam menganalisa mengeni perartuan kewenangan Notaris yang ditentukan berdasarkan ketentuan Pasal 15 UUJN-P, untuk mempermudah dalam pemahaman peraturan kewenangan Notaris dapat dibedakan menjadi 3 (tiga) diantaranya kewenangan umum, khusus, dan kewenangan lainnya.

\section{A. Kewenangan Umum.}

Dalam ketenuan pearturan mengenai kewenangan ini ditentukan berdasarkan ketetnuan Pasal 15 ayat (1). Dalam Pasal ini menentukan bahwa seorang Notaris berwenang untuk membuat akta autentik yang dikehendaki oleh yang berkepentingan untuk dinyatakan dalam akta autentik, mengenai semua perbuatan, perjanjian, penetapan, yang dalam pembuatanya berlandaskan ketentuan peraturan perundangundangan, menjamin kepastian tanggal ata tersebut dibuat, menyimpan akta, memberikan grosse akta, salinan dan kutipan akta. Semua perbuatan dalam pembuatan akta tersebut tidak dapat ditugaskan kecuali pejabat lain yang ditetapkan

\footnotetext{
${ }^{7}$ Mowoka, V. P. (2014). Pelaksanaan Tanggung Jawab Notaris terhadap Akta yang Dibuatnya. LEX ET SOCIETATIS, 2(4), hal.60

${ }^{8}$ Tjukup, I. K., Layang, I. W. B. S., Martana, N. A., Markeling, I. K., Dananjaya, N. S., Putra, I. P. R. A., ... \& Tribuana, P. A. R. (2016). AKTA NOTARIS (AKTA OTENTIK) SEBAGAI ALAT BUKTI DALAM PERISTIWA HUKUM PERDATA. Acta Comitas. hal. 182

${ }^{9}$ Ridwan HR, (2008), Hukum Administrasi Negara. Raja Grafindo. Jakarta. hal. 104

${ }^{10}$ Diana, P. V. P., Mertha, I. K., \& Artha, I. G. (2015). PERTANGGUNG JAWABAN NOTARIS DALAM PEMBUATAN AKTA BERDASARKAN PEMALSUAN SURAT OLEH PARA PIHAK. Acta Comitas, 161-172. hal.163
} 
oleh undang-undang. Pada itinya dalam ketentua Pasal ini bahwa seorang Notaris memiliki suatu kewenangan untuk membuat akta autentik.

Berdasarkan ketentuan Pasal 1868 KUH Perdata yang dimaksud dengan akta autentik adalah suatu akta yang dalam bentuknya ditentukan berdasarkan ketentuan undangundang, dibuat oleh atau dihadapan pegawai-pegawai umum yang berkuasa untuk itu ditempat dimana akta tersebut dibuat. Mengenai definisi yang ditentukan dalam ketentuan undang-undang tersebut menegaskan bahwa suatu akta autentik dapat dinyatakan sebagai akta apabila memiliki tiga (3) unsur dimna unsur-unsur tersebut adalah:

a. Bentuk dalam pembuatan akta/anatomi akta ditentuakan dalam ketentuan undang-undang;

b. Akta autentik harus dibuat Pejabat Umum yang diberikan kewenangan untuk membuat akta tersebut;

c. Akta autentik dalam pembuatanya harus dibuat oleh Pejabat Umum dalam lingkungan wilayah kerjanya.

Berkaitan dengan ketentuan Pasal 15 UUJN-P jika dihubungkan dengan ketentuan Pasal 1868 KUHPerdata sangat memiliki satu keterkaitan dalam kewenangan Notaris sebagai pembuat akta autentik. Keterkaitan tersebut yakni:

a. Akta autentik yang dibuat oleh Notaris berdasarkan ketentuan Undang-Undang merupakan alat bukti yang tidak perlu dibuktikan dengan alat bukti lainya;

b. Mengenai semua perbuatan hukum yang berkaitan dengan perjanjian dan penetapan, diharuskan oleh ketentuan peraturan umum atau atas permintaan dari penghadap dan dibuat oleh Notaris;

c. Segala hal produk hukum Notaris dibuat oleh dan dihadapan Notaris dimana dia berkuasa untuk itu ditempat dalam jabatanya tersebut.

Mengenai keterkaitan dalam ketentuan Pasal 1868 KUHPerdata, akta Notaris dalam ketentuan Pasal 1 angka 7 UUNJ-P bahwa akta autentik yang dibuat oleh atau dhadapan Notaris menurut bentuk dan tatacara yang ditetapkan dalam ketentuan undang-undang ini. Akta dapat berfungsi sebagai alat bukti yang didalamnya terdapat tanda tangan yang dibuat dengan sengaja untuk pembuktian dan memuat tentang suatu catatan peistiwa yang menjadi dasar suatu hak perikatan.

\section{B. Kewenangan Khusus.}

Kewenangan Notaris sesuai ketentuan Pasal 15 ayat (2) masuk dalam klasifikasi kewenangan khusus Notaris selain membuat akta autentik. Notaris kewenangannya dalam arti yang khusus terdiri dari mengesahkan tandatangan dan penetapan kepastian terhadap apa yang di sahkan.

Sesuai pejelasan dalam ketentuan Pasal 15 ayat (2) huruf a Notaris mempunyai kewenangan khusus untuk melegalisasi terhadap akta dibawah tangan yang dibuat oleh penghadap diatas kertas yang bermeterai cukup dengan mendaftarkan dalam buku khusus yang disediakan oleh Notaris. Legalisasi merupakan mengesahkan suatu surat yang dibuat dibawah tangan, surat tersebut ditandatangani dihadapan Notaris dan isi dari surat tersebut selanjutnya dibacakan oleh Notaris untuk kemudian diberi tanggal dan ditandatangani oleh para pihak yang kemudian dilegalisasi oleh Notaris. 
Kewenangan yang ditentukan di Pasal 15 ayat (2) huruf c kewenangan Notaris untuk membuat kopi dari asli surat dibawah tangan terdapat kelemahan. Kelemahan dari mengkopi dengan aslinya adalah menyalin gambar apabila dalam penjanjian dibawah tangan terdapat gambar yang diperjanjikan. Dalam ketentuan Pasal 15 ayat (2) huruf d sama halnya dengan kewenangan Pasal 15 ayat (2) hurf c. Kelemahan kewenangan ini adalah bagaimana mekanisme atau cara Notaris untuk memastikan kebenaran atau keaslian dari kopi surat yang diberikan para pihak mengingat teknologi seperti sekarang saat ini sangat canggih untuk melihat kaslian dari kopi asli tidak dapat dilaksanakan secara maksimal oleh Notaris. Contohnya adalah dalam melakukan pengesahan suatu kecocokan fotokopi surat kartu tanda penduduk (KTP) untuk mengetahui keaslian dari KTP kcocokanya keaslinya hanya dapat dilakukan oleh Kepala Dinas Kependudukan dan Catatan Sipil. Terkait dengan kewenangan tersebut dalam melakukan pengesahan kecocokan fotokopi dalam ketentuan UUJN-P tidak dibatasi dalam kewenangan menganai surat apa saja yang dapat dilegalisir oleh Notaris.

\section{Kewenangan Lain Notaris.}

Kewenangan lain ini ditentukan dalam Pasal 15 ayat (3) UUJN-P. Notaris memiliki kewenangan lain dalam peraturan perundang-undangan.Yang dimaksud dengan kewenangan lain antara lain kewenangan mensertifikasi transaksi yang dilakukan secara elektronik (cyber notary).

Sertifikasi dalam pengertian Kamus Besar Bahasa Indonesia (selanjutnya disebut KBBI) adalah pennyertifikatan. Berdasarkan ketentuan Pasal 1 angka 2 Undang-Undang Nomor 11 Tahun 2008 tentang Informasi Dan Transaksi Elektronik menentukan bahwa Transaksi Elektronik adalah perbuatan hukum yang dilakukan dengan komputer, jaringan komputer, dan/atau media elektronik lainnya. Dari penjelasan diatas dapat diartikan mensertifikasi dalam kewenangan Notaris adalah melakukan pengesahan atau mengautentikan sebuah akta dari substansi produk sebagai pengakuan terhadap produk hukum melaui media komputer, jaringan komputer dan/atau media elektronik lainnya. Sesuai dengan kewenangannya seorang Notaris yang diangkat oleh Negara, mempunyai kewenangan mensertifikasi transaksi yang dilakukan secara elektronik merupakan kewenangan untuk mencari solusi terhadap berbagai hambatan yang dihadapi. Peran seorang Notaris yang paling kuat dalam mendukung suatu transaksi elektronik apabila para pihak menghendaki dalam pembuatan suatu akta yang bebentuk elektronik. Akan tetapi peran Notaris dalam transaksi elektronik tersebut sebagai Registration Authority (RA) mencatatkan dan dituangkan dalam akta elektronik.

Pemahaman mengenai Pasal 15 ayat (3) dapat juga diartikan kewenangan Notaris memiliki fungsi lain yang diatur dalam peraturan perundang-undangan serta merupakan ketentuan kewenangan yang diatur pada masa akan akan datang atau ditentukan dikemudian hari (ius constituendum). Kewenangan Notaris yang ditentukan dimasa yang akan datang tersebut merupakan peraturan perundang-undangan yang dibentuk oleh lembaga Negara yaitu Dewan Perwakilan Rakyat Republik Indonesia hal tersebut dikarenakan kewenangan Notaris merupakan kewenangan atributif.

\subsection{Kepastian Hukum Kewenangan Notaris Dalam Melakukan Pengesahan Kecocokan Fotokopi Dengan Surat Aslinya.}


Profesi Notaris apabila dijalankan mempunyai resiko yang cukup tinggi dan sangat rentan terkena jerat hukum. Hal ini dapat terjadi karna faktor internal dan faktor eksternal. Faktor internal Notaris itu sendiri seperti keteledoran, melanggar prosedur, hingga tidak patuh dalam melaksanakan ketentuan etika profesi . Faktor eksternal Notaris yakni dihadapkannya pada dokumen palsu yang dalam hal ini dokumen tersebut memiliki kesesatan fakta hukum yang memiliki konsekwensi hukum bagi pemiliknya. ${ }^{11}$

Notaris dalam melaksanakan kewenangannya untuk melakukan pengesahan kecocokan foto kopi dengan surat aslinya, merupakan produk yang dihasilkan oleh Notaris pada saat melakukan legalisasi dan warmerking. Legalisasi yang dilakukan oleh Notaris merupakan suatu surat yang dibuat oleh para pihak, akan tetapi dalam proses penandatangannya disaksikan oleh dan/atau dihadapan Notaris. Dalam melaksanakan legalisasi surat tersebut Notaris tidak memiliki tanggung jawab terhadap isi dari dokumen tersebut. Dalam melaksanakan legalisasi tersebut Notaris hanya memiliki tanggung jawab terhadap tanda tangan serta tanggal pada saat melakukan penandatangan yang bersangkutan sebagai para pihak yang terdapat dalam surat tersebut. waarmerking merupakan akta dibawah tangan yang sudah ditandatangani oleh para pihak kemudian didaftarkan untuk memberi tanggal kepastian telah adanya suatu perbuatan hukum. Pada saat melaksanakan waarmerking Notaris tidak menjelasakan siapa yang berhak untuk menandatangani dan apakah dalam penandatangan surat yang diwaarmerking para pihak sudah memahami isi dari akta tersebut. Lebih tepatnya dalam proses waarmerking Notaris tidak bertanggung jawab terhadap materi/isi dan tanda tangan para pihak dalam dokumen yang dibuat oleh para pihak. ${ }^{12}$ Akan tetapi Notaris memiliki tanggung jawab terhadap kepastian tanggal dalam melaksanakan pendaftaran surat atau dalam melaksanakan waarmerking.

Selain kewenangan Notaris dalam melakukan Waarmerking dan Legalisasi sebagaimana tersebut diatas, Notaris juga memiliki suatu kewenangan melakukan pencocokan fotocopy. Dalam praktek mencocokan fotokopi suatu dokumen dengan aslinya Notaris menandatangani fotokopi dokumen serta diberikan cap dengan judul Pencocokan Fotokopi dan distempel/cap disetiap halaman yang di fotocopi dengan paraf Notaris dan halaman terakhir dari pencocokan Fotocopy tersebut akan dicantumkan keterangan bahwa fotocopy tersebut sama dengan aslinya. ${ }^{13}$

Untuk keperluan legalisasi, warmerking, ataupun legalisir para pihak penanda tangan harus datang menghadap Notaris. Notaris kemudian memeriksa tanda pengenal, yaitu KTP atau tanda pengenal lainnya. Pengertian tanda pengenal dalam hal ini Notaris harus memahami dengan benar penghadap sesuai dengan kartu identitasnya, bahwa orangnya yang datang itu memang sama dengan kartu pengenalnya, dia memang orangnya, yang bertempat tinggal sesua dengan alamat yang terdapat pada tanda pengenal, gambarnya sesuai. Sesudah diperiksa cocok, kemudian Notaris melakukan

${ }^{11}$ Mansyur, A. A. S. (2013). Analisis Yuridis Normatif Terhadap Pemalsuan Akta Otentik Yang Dilakukan Oleh Notaris. Kumpulan Jurnal Mahasiswa Fakultas Hukum, 1(2). hal.3.

${ }^{12}$ Ghofur, Abdul. Loc.cit.

${ }^{13}$ Dinaryanti, A. R. (2013). Tinjauan Yuridis Legalisasi Akta Di Bawah Tangan Oleh Notaris. Legal Opinion, 1(3).hal.16. 
analisa dan memberikan keputusannya tentang produk hukum apa yang akan ia berikan dengan menyesuaikan terhadap fakta hukum dan dokumen hukum yang ia terima.

Notaris dalam menjalankan kewenangan ketentuan Pasal 15 ayat (2) huruf d UUJN-P masih memiliki ruang penafsiran dan penulis menemukan adanya kesulitan untuk melakukan legalisir. Ketentuan pasal tersebut tidak menjelaskan surat aapa saja yang Notaris dapat dilegalisir dan bagaimana cara Notaris melakukan legalisir fotokopi surat yang sesuai dengan aslinya. Penafsiran Pasal tersebut mengartikan Notaris dapat melakukan semua pengesahan kecocokan fotokopi surat dengan surat aslinya untuk surat-surat yang dibuat oleh siapa saja baik perorangan maupun instasi. Kedepannya pasal ini hendaknya direvisi agar lebih jelas dan pasti bagi Notaris dalam menjalan kewenangannya. Contoh lainnya adalah seperti halnya Pejabat Catatan Sipil melakukan pengesahan kecocokan fotokopi Kartu Tanda Penduduk (KTP). Melihat kewenangan tersebut artinya siapa saja dapat melakukan tindakan hukum untuk melakukan pengesahan fotokopi surat yang dikeluarkan oleh instasinya.

Seorang Pejajabat Catatan Sipil dapat melakukan hal tersebut dikarenakan yang menerbitkan fotokopi KTP adalah pejabat catatan sipil. Dalam melaksanakan legalisir kecocokan tersebut artinya Pejabat Catatan Sipil dapat memastikan kebenaran fotokopi KTP tersebut dikarenakan Pejabat Catatan Sipil memiliki data mengenai kependudukan yang akan dilegalisir. Melakukan pengesahan tersebut dapat memastikan mengenai keaslian dari fotokopi yang akan dilegalisir.

Notaris memiliki kewenangan untuk memberikan pengesahan kecocokan fotokopi dengan surat aslinya untuk surat-surat apa saja yang dibuat oleh siapa saja dalam hal ini membuat tidak adanya batasan dan bagamana cara Notaris memastikan kebenaran dari asli surat yang diberikan oleh para pihak untuk melagalisasi surat tersebut.

\subsection{Kewenangan Notaris Dalam Memastikan Kebenaran Kesesuaian Fotokopi Dengan Surat Aslinya.}

Berdasarkan ketentuan Pasal 164 Het Herziene Indonesisch Reglement (HIR), Pasal 284 Reglement Tot Regeling Van Het Rechtswezen In De Gewesten Buiten Java En Madura (Rbg.) alat yang biasanya digunakan dalam Hukum Acara Perdata bahwa bukti yang diakui oleh hukum terdiri dari: Bukti Tertulis. (Pasal 1867KUH Perdata,Bukti Saksi. (Pasal 1895 Perdata), Persangkaan, (Pasal 1951 KUH Perdata), Pangakuan. (Pasal 1923 KUH Perdata), Sumpah. (Pasal 1929 KUH Perdata). Begitupun dalam Pasal 184 ayat (1) Undang-Undang Nomor 8 Tahun 1981 Tentang Hukum Acara Pidana yang di undangkan di Jakarta pada tanggal 31 Desember 1981, Disahkan di Jakarta Pada tanggal 31 Desember (Selanjutnya disebut dengan KUHAP) menentukan alat bukti yang sah diantaranya Keterangan Saksi, Keterangan Ahli, Surat,Petunjuk, Keterangan terdakwa. Ketentuan pasal mengenai pembuktian dalam hukum acara perdata dan pidana mengakui bahwa alat bukti tertulis dapat digunakan sebagai alat bukti yang sah. Dalam penulisan jurnal ini fokusnya pada alat bukti tertulis/surat sesuai HIR dalam ketentuan Hukum Acara Perdata merupakan alat bukti yang sah. Mengenai pemahaman surat tersebut dapat diartiakan bahwa alat bukti tertulis yakni surat merupakan kertas yang berisikan tulisan informasi mengenai suatu hal dari orang yang ditujukan dan/atau disampaikan kepada orang lain serta dalam surat tersebut 
memuat informasi berupa pemberitahuan, pertanyaan, permintaan, laporan dan sebagainya.

Pemahaman surat dapat diartikan bahwa alat bukti tertulis yakni surat dapat berupa surat dibawah tangan atau autentik. Pada dasarnya surat dibawah tangan merupakan surat yang dibuat oleh para pihak, diakui dan tunduk pada surat tersebut, sedangkan surat autentik merupakan surat yang dibuat oleh Pejabat Umum yang berwenang dalam pembuatan surat tersebut dimana dalam pembuatannya ditrntukan oleh Undang-Undang. Berdasarkan ketentuan Pasal 1866 KUH Perdata alat bukti tertulis dibagi menjadi 2 (dua) yaitu surat yang merupakan akta dan surat-surat lainya yang bukan akta. Berdasarkan ketentuan Pasal 1868 KUH Perdata menentukan akta autentik ialah akta yang isinya ditentukan oleh undang-undang, dibuat oleh atau di hadapan pegawai-pegawai umum yang berkuasa untuk itu dimana akta itu dibuatnya. Berdasarkan Pasal 1874 KUH Perdata menentukan tulisan-tulisan dibawah tangan dianggap seabagai akta-akta yang ditandatangani dibawah tangan, surat-surat, register-register, surat-surat urusan rumah tangga dan lain-lain tulisan yang dibuat tanpa perantaraan seorang pegawai umum. Memahami keetentuan pasal tersebut baik surat yang berbentuk akta autentik maupun akta dibawah tangan dapat dipergunakan untuk tujuan sebagai alat bukti yang sah. Perbedaan yang terpenting terhadap dua jenis surat akta autentik dan akta dibawah tangan bahwa akta autentik lebih mempunyai pembuktian yang sempurna. ${ }^{14}$ Akta autentik yang memiliki pembuktian yang sepurna ini mengartikan bahwa alat bukti akta autentik tidak perlu kembali dibuktikan dengan alat bukti alainya.

Notaris yang merupakan sebagai Pejabat Umum pada dasarnya membuat akta autentik dan dalam pembuatannya ditentikan dalam ketentuan Undang-Undang, oleh karena itu akta Notaris dapat diakui sebagai alat bukti yang sempurna. Akta Notaris sebagai alat bukti pada intinya harus dilihat apa adanya, bukan ada apanya, sehingga kesempurnaan terhadap akta autentik tidak perlu ditafsirkan lain selain yang tertulis dalam akta tersebut . ${ }^{15}$ Sedangkan terhadap akta dibawah tangan mempunyai kekuatan pembuktian sepanjang para pihak mengakuinya isi dari pembuatan akta surat tersebut. ${ }^{16}$

Tugas pokok dan fungsi Notaris selain yang ditentukan oleh Undang-Undang untuk membuat akta autentik, Notaris juga memiliki kewenangan untuk melakukan pendaftaran dan pengesahan akta dibawah tangan dan copy surat yang sesuai dengan aslinya (legalisisr dan waarmerrking). Dalam melakukan Legalisir yang dilakukan oleh Notaris merupakan pengesahan akta dibawah tangan. ${ }^{17}$ Akta dibawah tangan yang dibacakan oleh Notaris pada waktu melakukan legalisir pada dasarnya Notaris mejamin kepastian tanggal surat yang dilegalisir pada waktu itu.

${ }^{14}$ Adjie, Habb. (2015), Kebatalan Dan Pembatalan Akta Notaris Cet II. Bandung : Refika Aditama. hal. 7.

${ }^{15} \mathrm{Ibid}$.

${ }^{16} \mathrm{Ibid}$.

${ }^{17}$ Puspa, W. T., Harjono, H., \& Winarno, D. W. (2016). Tanggungjawab Notaris terhadap Kebenaran Akta Dibawah Tangan yang Dilegalisasi oleh Notaris. Repertorium, 3(2). hal.157. 
Kewenangan Notaris dalam memastikan kebenaran kesesuaian fotokopi dengan surat aslinya apakah memiliki kewenangan atau tidak dalam kajian penulis adalah Notaris memiliki kewenangan yang diatur dalam ketentuan Pasal 15 ayat (2) huruf d UUJN-P. Namun dalam hal ini kedepannya perlu dilakukan pembenahan mengingat UUJN-P tidak memberikan kepastian hukum sejauh mana kewenangan Notaris dalam melakukan pengesahan kecocokan fotokopi dengan surat aslinya dan tidak memberikan kejelasan pemahaman tentang bagaimana cara Notaris untuk melakukan pencocokan serta surat apa saja yang bisa dilakukan pengesahan pencocokan oleh Notaris.

Dalam hal Notaris melakukan kesalahan dalam memastikan kebenaran kesesuaian fotokopi dengan surat aslinya Notaris bertanggung jawab secara hukum. Tanggung jawab secara hukum merupakan suatu kesadaran manusia terhadap tingkah laku perbuatan baik disengaja maupun yang tidak disengaja. ${ }^{18}$ Dapat juga dikatakan bahwa tanggung jawab secara hukum merupakan kewajiban menanggung segala yang menjadi tugas dari segala tindakan yang baik maupun yang buruk. Oleh karena itu dalam kajian hukum administrasi negara melakukan tindakan wewenang yang diperoleh secara organ pemerintah, sangat sejalan dengan salah satu asas negara hukum yakni tidak ada wewenang tanpa tanggung jawaban. ${ }^{19}$ Tindakan atau perbuatan yang baik, merupakan kewajiban untuk menjalankan peraturan - peraturan dengan baik atau sesuai yang ditentukan. Apabila menjalankan suatu peraturan dengan tidak baik atau perbuatan buruk berarti akan memikul akibat tindakan perbuatan buruk tersebut.

Menurut pendapat Purwahit Patrik yang di kutip oleh Sjaifurrachman dalam bukunya aspek pertanggung jawaban dalam pembuatan akta 20 , bahwa tanggung jawab merupakan hasil seseorang yang harus memikul untuk menanggung menjawabkan terhadap semua perbuatan yang menjadi kewajiban beserta segala akibatnya. Mengenai pendapat tersebut dapat diartikan bahwa tanggung jawab Notaris dalam peraturan-peraturan yang berkaitan dengan Notaris, terikat terhadap ketentuanketentuan hukum pada saat Notaris menjalankan tugas dan kewajibanya. Pengertian tersebut dalam arti kata semua perbuatan Notaris menjalankan tugasnya harus bertanggungjawab dan dapat dipertanggung jawabkan secara hukum apabila melaksanakan ketentuan peraturan perundang-undangan dengan tidak baik dan mempertanggung jawabkan sesuai dengan tingkat kesalahannya.

\section{Kesimpulan}

Adapun kesimpulan terkait dengan kajian permasalahan dalam jurnal penelitian ini adalah : Kepastian hukum Pasal 15 ayat (2) huruf d UUJN-P terkait kewenangan Notaris dalam melakukan pengesahan kecocokan fotokopi dengan surat aslinya masih terdapat kekaburan norma hukum, yang tidak memberikan kejelasan pemahaman tentang bagaimana cara Notaris untuk melakukan pencocokan surat asli yang

${ }_{18}$ Purbacaraka. (2010), Perihal Kaedah Hukum. Bandung: Citra Aditya. hal 37.

${ }^{19}$ Parsa, I. W., Sarna, K., \& Suharta, N. IMPLIKASI YURIDIS LEGALITAS KEWENANGAN (RECHTMATIGHEID) MAJELIS KEHORMATAN DALAM PEMBINAAN NOTARIS SEBAGAI PEJABAT PUBLIK. Acta Comitas. hal.168.

20Sjaifurrachman \& Adjie, H. (2011). Aspek Pertanggungjawaban Dalam Pembuatan Akta. Bandung: Madar Maju. hal. 15 
penghadap bawa dan apa saja yang dapat dilakukan pengesahan dari surat asli tersebut

Kewenangan Notaris dalam memastikan kebenaran kesesuaian fotokopi dengan surat aslinya, dalam kajian penulis adalah Notaris memiliki kewenangan yang diatur dalam ketentuan Pasal 15 ayat (2) huruf d UUJN-P namun dalam hal ini kedepannya perlu dilakukan pembenahan mengingat UUJN-P tidak memberikan kepastian hukum sejauh mana kewenangan Notaris dalam melakukan pengesahan kecocokan fotokopi dengan surat aslinya.

\section{Daftar Pustaka}

Buku

Adjie, H. (2008), Hukum Notaris Indonesia (Tafsir Tematik Terhadap UU No.30 tahun 2004 Tentang Jabatan Notaris). Bandung: Refika Aditama.

. (2015). Kebatalan Dan Pembatalan Akta Notaris Cet III. Bandung: Refika Aditama.

Ali, Z. (2009). Metode Penelitian Hukum. Jakarta: Sinar Grafika.

Ghofur, A. (2009). Lembaga Kenotariatan Indonesia. Yogyakarta: UUI Press.

Purbacaraka. (2010). Perihal Kaedah Hukum. Bandung: Citra Aditya.

Ridwan. (2008). Hukum Administrasi Negara. Jakarta: Raja Grafindo.

Sjaifurrachman \& Adjie, H. (2011). Aspek Pertanggungjawaban Dalam Pembuatan Akta. Bandung: Madar Maju.

\section{Jurnal}

Diana, P. V. P., Mertha, I. K., \& Artha, I. G. (2015). PERTANGGUNG JAWABAN NOTARIS DALAM PEMBUATAN AKTA BERDASARKAN PEMALSUAN SURAT OLEH PARA PIHAK. Acta Comitas, 161-172. https://ojs.unud.ac.id/index.php/ActaComitas/article/view/34268

Diatmika, I. G. A. O., Atmadja, I. D. G., \& Utari, N. K. S. (2014). Perlindungan Hukum Terhadap Jabatan Notaris Berkaitan Dengan Adanya Dugaan Malpraktek Dalam Proses Pembuatan Akta Otentik. Acta Comitas, 150-160. https://ojs.unud.ac.id/index.php/ActaComitas/article/view/34267

Dinaryanti, A. R. (2013). Tinjauan Yuridis Legalisasi Akta Di Bawah Tangan Oleh Notaris. Legal https://media.neliti.com/media/publications/150428-ID-none.pdf

Hendra, R. (2011). Tanggungjawab Notaris Terhadap Akta Otentik Yang Penghadapnya Mempergunakan Identitas Palsu di Kota Pekanbaru. Jurnal Ilmu Hukum Riau, 3(01).

https://media.neliti.com/media/publications/9131-ID-tanggungjawabnotaris-terhadap-akta-otentik-yang-penghadapnya-mempergunakan-iden.pdf

Haris, M. (2018). Kewenangan Notaris sebagai Pejabat Lelang Kelas II dalam Memberikan Penyuluhan Hukum atas Akta Risalah Lelang yang Dibuatnya. Syariah: Jurnal Hukum dan Pemikiran, 17(1). https://media.neliti.com/media/publications/257135-kewenangan-notarissebagai-pejabat-lelan-b167ef6a.pdf.

Mansyur, A. A. S. (2013). Analisis Yuridis Normatif Terhadap Pemalsuan Akta Otentik Yang Dilakukan Oleh Notaris. Kumpulan Jurnal Mahasiswa Fakultas Hukum, 1(2). http://hukum.studentjournal.ub.ac.id/index.php/hukum/article/viewFile/24 $\underline{6 / 238}$ 
Mowoka, V. P. (2014). Pelaksanaan Tanggung Jawab Notaris terhadap Akta yang Dibuatnya. LEX ET SOCIETATIS, 2(4).

https://ejournal.unsrat.ac.id/index.php/lexetsocietatis/article/viewFile/4671 $\angle 4199$

Parsa, I. W., Sarna, K., \& Suharta, N. IMPLIKASI YURIDIS LEGALITAS KEWENANGAN (RECHTMATIGHEID) MAJELIS KEHORMATAN DALAM PEMBINAAN NOTARIS SEBAGAI PEJABAT PUBLIK. Acta Comitas. https://ojs.unud.ac.id/index.php/ActaComitas/article/view/24901/16145

Puspa, W. T., Harjono, H., \& Winarno, D. W. (2016). Tanggungjawab Notaris terhadap Kebenaran Akta Dibawah Tangan yang Dilegalisasi oleh Notaris. Repertorium, 3(2).

https://media.neliti.com/media/publications/213250-tanggungjawab-notaristerhadap-kebenaran.pdf

Tjukup, I. K., Layang, I. W. B. S., Martana, N. A., Markeling, I. K., Dananjaya, N. S., Putra, I. P. R. A., ... \& Tribuana, P. A. R. (2016). AKTA NOTARIS (AKTA OTENTIK) SEBAGAI ALAT BUKTI DALAM PERISTIWA HUKUM PERDATA. Acta

Comitas. https://ojs.unud.ac.id/index.php/ActaComitas/article/view/24902/16146 